\title{
A Case Study of Sandplay Therapy for an Adolescent Boy with Emotional Difficulties
}

\author{
Hee-og Sim ${ }^{1}$ \\ Professor, Department of Child \& Family Studies, Kunsan National University, Kunsan, Korea ${ }^{1}$ \\ 정서문제로 의뢰된 청소년의 모래놀이치료 사례연구 \\ 심희옥 ${ }^{1}$ \\ 군산대학교 아동가족학과 교수 ${ }^{1}$
}

\begin{abstract}
Objectives: This study explored the sandplay therapy case of a middle school boy with emotional difficulties. The goal of the therapy was to lessen his emotional difficulties by providing a free and protected space through sandplay therapy. Thirty-three therapy sessions were held. The client showed the scene of empty buildings in the shape of a mandala and a scene of regression in the initial phase of therapy (1-2, A sense of emptiness and regression). In the intermediate phase of therapy (3-27, Struggle), he showed fierce wars and made a slapping sound with water and sand and exhibited the ending of wars. In the final phase of therapy (28-33, The active daily life), he showed a motorcycle race, strong masculinity and village scenes. During the therapy, archetypal patterns, such as regression to the archetypal mother and wars appeared. Sandplay therapy, in a free and protected space, lessened the emotional difficulties of the client. Thus, this study is a demonstration of the effectiveness of sandplay therapy.
\end{abstract}

Keywords: sandplay therapy, adolescent, emotional difficulties, internalization problems

\section{Introduction}

청소년기는 아동기에서 성인기로 이행하는 시기로 신체적 으로 빠르게 성장하고 정신적으로 독립에 대한 욕구와 자아 에 대한 개념이 좀 더 확고해지는 때이다. 청소년은 사춘기 의 생리적인 변화와 함께 학업 성취, 사회성, 운동 등에서 수 행 압력 또한 겪는다. 청소년의 문제 행동이 시간이 지나면 자연스럽게 없어지는 성장통 만은 아닐 수 있어 청소년의 정 신건강은 중요한 이슈다(Song, 2017). 심리학적으로 청소년 기는 아동기까지 가족의 보호를 받다가 이제는 부모와의 동 일시에서 벗어나 새로운 정체감을 발달시켜야 할 중요한 시 기로 이런 변화는 청소년에게 매우 고통스러워 심리적인 죽

Corresponding Author: Hee-og Sim, Professor, Department of Child \& Family Studies, Kunsan National University, Daehak-ro 558, Gunsan-si, Jeollabuk-do Korea

E-mail: simh@kunsan.ac.kr
음과 재생의 시기로 여겨진다(Prins-Goodman, 2012; Sim, 2014). 청소년은 내면의 변화와 외부의 다양한 요구를 겪으 며 우울, 불안, 좌절과 같은 정서 변화로 이에 반응하는 경향 이 많기 때문에(M. K. Lee, 2015) 특히 이런 정서적인 어려움 을 호소하는 청소년에 대한 관심이 필요하다. 청소년의 어 려움 특히 위축, 우울, 불안 같은 정서, 내재화 문제는 외현 화 문제와는 다르게 청소년 자신을 다양한 모습으로 힘들게 하며 필요이상으로 심리내면에 고통을 주어 학업과 같은 주 어진 발달과업에 정진하지 못하게 하고 삶을 피폐하게 할 수 있어 외부의 도움을 절대 필요로 한다.

모래놀이치료는 모래상자에 다양한 소품들을 가지고 내담 자가 자신의 마음의 세계를 만드는 언어에 거의 의존하지 않

(C)The Korean Association of Child Studies

This is an Open Access article distributed under the terms of the Creative Commons Attribution Non-Commercial License (http:// creativecommons.org/licenses/by-nc/4.0) which permits unrestricted noncommercial use, distribution, and reproduction in any medium, provided the original work is properly cited. 
는 심리치료법으로 말이 많지 않거나 타인과의 대화를 어려 워하는 청소년들에게 부담을 적게 주어 치료자와 내담자가 좀 더 가벼운 마음으로 행할 수 있다. 모래놀이치료에서 치료 공간과 모래상자가 자유롭고 보호된 공간(free and protected space)이 되어 내담자는 자기 자신이 있는 그대로 받아들여진 다는 느낌을 가질 수 있다. 모래놀이치료는 어머니와 자녀의 관계처럼 품어주는 공간을 만들어 내담자 내면에 있는 스스로 치료하는 힘을 일깨워 주고 내담자가 자기 스스로를 돌아보게 한다(Kalff, 2003; Sim, 2014).

모래놀이치료에서 모래는 어머니의 몸을 상징하기도 한 다(Bradway, Chambers, \& Chiaia, 2005). 예를 들어, 어머니 와의 접촉의 욕구를 충분히 채우지 못한 내담자들이 모래를 만지는 행위는 어머니를 만지는 것과 같아 결여된 욕구를 채 우게 해 준다. 어머니와 좋은 관계를 맺지 못한 내담자는 모 래 만지기를 굉장히 꺼려하기도 한다. 물론 여기서 모는 개 인적인 모보다는 원형적인 모, 태고의 정신으로 온전한 인 간 능력의 잠재력을 의미하며, 모에게 회귀하는 것은 발달되 지 못한 자신의 귀중한 부분을 되찾기 위함이다(Henderson, 2005).

모래놀이치료에서는 우리의 마음이 붙들고 있는 것을 몸의 일부인 손이 드러나게 해준다(Montecchi, 1999; Sim, 2014; Talamini, 2010). 즉, 모래를 만지고 모래상자 안에 소 품을 놓으며 손은 내적인 갈등, 감춰진 개인생활의 사건을 드러나게 해 준다(Montecchi, 1999; Sim, 2014). 손은 때로 비 밀을 드러내며 말보다 더 분명히 말하고, 상처를 극복하거 나 치유하는데 필요한 에너지가 소통하게 만들어 내담자의 손이 표현한 것을 치료자는 온몸과 마음으로 경청해야 한다 (Jang, 2017).

한편, 신경과학에 의하면, 우리는 태아기부터 시작된 정서 의 역사를 기억한다(Napoliello, 2013). 어릴 적의 태도나 감정 이 암묵적인 기억, 정서적인 기억에 남아 있는데 내담자는 심 리치료로 이런 과거를 기억해 낸다. 손의 활동은 뇌의 감각운 동 피질의 많은 영역이 담당하는데 이 때 손처럼 감각적인 기 능을 할 수 있는 기관이 억압되거나 잊혀진 정서를 기억해 내 게 돕는다.

손을 사용하는 모래놀이치료에서 놀이는 의도하지 않는 것 으로 놀이의 무의도성이 긴장, 불안과 경직된 사고방식을 사 라지게 한다(Kalff, 2003; Sim, 2014). 이로써 모래놀이를 하는 사람 안에 예기치 않았던 힘과 용기가 발견되어 결국 모래놀 이치료가 진행되면서 치료시작 당시에 빠졌던 혼란 상태에서 서서히 내적인 질서가 생기게 된다(Kalff, 2003; Sim, 2014).
모래놀이치료로 청소년의 정서 관련 어려움을 도운 국내 연구들이 있다. 중학교 남학생을 대상으로 학교부적응, 정 서적인 혼란과 우울이 완화된 사례(H. J. Kim, 2011), 정서문 제, 내재화 및 외현화 문제해결에 효과를 밝힌 연구(J. A. Kim, 2015), 그리고 심리적인 혼란과 갈등, 불안을 해소시킨 사례 연구(Yun, 2017)가 있다. 또한 자기표현에 어려움이 있는 고등 학생들이 모래놀이치료로 자기표현이 향상되고 자아존중감 과 대인관계가 향상된 것에 대한 연구도 있다(Jeon, 2007). 그 런데 이런 연구 대부분은 내담자의 내면과 내면의 흐름 같은 것을 탐색하는데 주안점을 두기 보다는 주로 주호소 문제해결 에 초점을 두어 정서적인 어려움을 지닌 청소년이 어떻게 자 신의 갈등이나 어려움을 표현하고 치유해 가는지 등 내면세계 를 이해하는 데는 한계가 있다. 내면세계에 대한 폭넓은 이해 가 우선되어야 궁극적으로 청소년의 어려움을 효과적으로 도 울 수 있어 이에 대한 연구가 필요하다. 사례연구는 어떤 특정 한 사람, 문제 및 상황을 깊이 있게 연구할 때 유용한 방법(Y. O. Kim et al., 2009)으로 특히 내면세계에 대한 밀도 있는 탐색 은 사례연구가 적합한 것으로 사료된다.

본 연구의 내담자는 중학교 3학년 남학생으로 부모와 출산 과정에서의 어려움으로 뇌병변 사지마비가 되어 휠체어 생활 을 하는 14 개월 터울의 여동생과 생활한다. 내담자는 지지적 인 부모 밑에서 착하고 학교나 가정에서 모범적으로 생활하지 만 본인이 가진 역량에 비해 소극적인 모습이 많고, 학교의 심 리검사에서 불안과 우울지수가 높았고, 숙면을 취하지 못하는 경우가 자주 있어 모에 의해 치료에 의뢰되었다. 이런 내담자 에게 모래놀이치료의 자유롭고 보호된 공간을 제공하여 내담 자의 정서적인 어려움이 완화되어 가정과 학교에서 보다 원만 하게 생활하는 것을 치료목표로 삼았다.

Turner (2005)는 모래놀이에서의 치유와 변화과정을 추적 하기 위해 모래상자를 내용주제, 공간주제, 정서주제, 동작주 제로 파악하는데, 본 연구는 모래상자를 Turner (2005)의 가장 포괄적인 내용주제에 초점을 두어 분석심리학과 모래놀이치 료 이론의 관점에서 탐색하는 것을 목적으로 한다. 또한 본 연 구는 심리검사, 내담자와 모의 보고에 의한 행동평가 및 실생 활에서의 변화과정을 통해 정서적인 어려움을 호소하는 남자 청소년의 내면세계에 대한 이해의 폭을 넓히고 모래놀이치료 의 효과를 제시하려고 한다. 이는 학교현장과 상담 장면에서 청소년의 교육, 생활지도 및 상담에 활용될 수 있는 기초자료 를 제공할 수 있다. 


\section{Methods}

\section{연구대상}

\section{양육사 및 내담자의 상황}

본 연구의 대상은 중학교 3학년에 재학 중인 남학생(만 14.4 세)이다. 내담자는 부(만 46.1세), 모(만 42.4세)와 14 개월 터울 의 뇌병변 사지마비로 휠체어 생활을 하는 여동생(만 13.2세) 을 둔 가정에서 생활한다.

모는 결혼한 지 3 년 만에 임신하여 가족들의 축복을 받았으 나 시부가 임신기간 중에 사망하여 결혼 후 3년 내에 초상을 치루는 것은 며느리가 잘못 들어와서라고 생각하는 시모의 원 망을 많이 들어야 했다. 모의 임신중독으로 난산이었으나 내 담자는 건강하게 잘 자랐는데 낯가림은 심했다. 주산기의 어 려움으로 장애를 지니고 동생이 태어나 내담자는 고모집에 2 주정도 맡겨지고, 동생이 병원생활을 자주 할 때 외조모, 친척, 이웃 등에게 맡겨지기도 했다. 내담자는 부모와 관계가 좋으 며 여동생에게 가끔 짜증을 내지만 잘 챙겨주고 이야기도 잘 하는 편이다. 내담자는 초등학교 때부터 이어진 4-5명의 친한 친구가 있다. 가끔 친구들이랑 영화를 보고 당구와 볼링을 하 는데 모는 친구관계에서 내담자가 자기 것을 주장하기보다 친 구들의 뜻에 맞추는 것이 아닌가 한다. 내담자는 축구, 농구 등 체육활동을 싫어하고 성적은 우수한 편이고 또래보다 정치나 사회적인 면 등 관심사가 넓고 깊은 편이다. 내담자는 주위의 칭찬과 기대를 많이 받고 있고, 공부를 잘해서 인정받고 싶어 하는 면이 강하다. 내담자는 중학교 1학년 때 심리검사에서 불 안과 우울지수가 높았고, 중학교 2학년 때부터는 피곤하다며 숙면을 취하지 못한다는 표현을 자주했고 지난 겨울방학에는 “인생이 절망스럽다.”는 표현을 하기도 했다. 내담자는 본인 이 생각하는 것보다 훨씬 많은 능력을 가지고 있는 것 같은데 소극적인 모습이고, 불안하고 우울한 마음의 정화와 자존감, 자신감의 회복을 위해 모에 의해 치료에 의뢰되었다.

\section{치료 및 연구절차}

내담자에게 2016년 3월 26일 2017년 2월 22일까지 거의 1주 일에 한번 1 시간씩 총 33 회기의 모래놀이치료가 $\mathrm{K}$ 대학교 모 래놀이치료실에서 행해졌다. 모로부터 매주 주로 전자우편으 로 내담자의 실생활을 보고 받고 내담자의 처지, 생각, 마음상 태 등에 대해 안내하는 부모교육을 실시하였다. 사전과 사후
심리평가는 치료 첫 2회기와 마지막 2회기에 실시하였다. 사전 과 사후 객관 심리평가로 내담자는 Youth Self Report (YSR; K. J. Oh, Kim, Ha, Lee, \& Hong, 2010b)와 Minnesota Multiphasic Personality Inventory-Adolescent (MMPI-A; J. S. Kim et al. 2005) 에, 모는 Korea-Child Behavior Checklist (K-CBCL; K. J. Oh et al., 2010a)에 응답하고, 투사 심리검사로 House-Tree-Person (HTP), Kinetic Family Drawing (KFD), Kinetic School Drawing (KSD) 그 리고 Sentence Completion Test (SCT)를 실시하였다. 비교를 위 해 SCT를 제외한 사전, 사후 투사검사는 Appendix 1에 그리고 모래놀이치료 전체 회기 사진은 Appendix 2에 제시한다. 연구대 상자의 권리를 보호하고 연구자의 연구윤리 준수를 위해 보호 자로부터 모래놀이치료 과정과 심리검사 내용이 연구 목적으 로 사용되는 것에 대해 사전 동의를 받았다.

\section{심리검사}

객관검사로 $\mathrm{Oh}$ 등(2010b)의 청소년 자기행동 평가척도(YSR), $\mathrm{Oh}$ 등(2010a)의 아동.청소년 행동평가척도(K-CBCL), 그리고 J. S. Kim 등(2005)의 다면적 인성검사-청소년용(MMPI-A)을 실시하였다. 투사검사로는 집-나무-사람(HTP), 동적가족화 $(\mathrm{KFD})$ 와 동적학교화 $(\mathrm{KSD})$ 그리고 30 개 문항의 문장완성검사 (SCT)를 실시하였다.

\section{사례 개념화}

내담자의 어려움을 개인과 가족 측면에서 보면, 내담자는 낮 가림이 심했는데 주산기의 어려움으로 장애를 가진 14 개월 터울 여동생의 잦은 병원 입원으로 영아기부터 친척이나 이웃 의 손에 자주 맡겨지는 경험을 하였다. 여동생의 장애로 빚어 지는 육아 스트레스를 모는 내색하지 않으려 했지만 내담자에 게 짜증이나 꾸지람이 있었고 항상 병원과 복지관에 바쁘게 다니며 정신없이 생활하였다. 내담자는 지지적인 부모에게조 차도 요구를 잘 하지 못하고 불안해하며 밤에 불을 끄고 자지 못하는 등 수면의 어려움과 피곤함을 호소한다. 또한 사회문 화적인 측면에서 보면, 내담자는 학교에서 공부 잘하는 모범 생이지만 친구들과도 공유될 수 없는 생각이 가볍지 않은 애 어른 같은 모습이고, 친구 간에도 자기 표현력이 높지 않으며 학교활동에 소극적이다. 고등학교 공부, 성인이 되어 경험할 취업에 대한 걱정 등 미래에 대한 걱정이 많다.

내담자의 핵심문제는 불안으로 보여지는데 이런 문제의 원 인과 발생 배경은 영아시기부터 잦은 모와의 분리로 정서적으 
로 안정적이지 못한 것 때문일 수 있다. 영유아기 스트레스는 신경과학적으로도 정서규제와 관련된 우뇌발달에 어려움을 초래할 수 있다(Schore, 2002). 이와 더불어 동생의 장애가 주 산기의 어려움으로 생겼는데 이는 내담자에게 불가항력적인 불행으로 인식될 수 있는 생활사건으로 내담자의 기질적인 특 성과 더불어 미래에 대한 걱정과 두려움을 더욱 부추길 수 있 다. 또한 학업에 대한 스트레스가 많은데 이는 장애여동생을 두고 있어 가정에서의 성취에 대한 기대 등도 스트레스를 주 어 수면에 어려움을 주는 것일 수 있다. 유년시절의 부정적인 경험과 내담자의 높은 부정적인 정서성은 우울의 주요 위험요 인인데(American Psychiatric Association, 2013), 우울의 전형적 인 증상으로 내담자는 우울한 기분, 자신감의 상실, 피로감, 미 래에 대한 절망적인 생각, 수면장애 등을 보인다. 이런 문제를 해결하기 위한 전략으로 치료자는 내담자가 영유아기부터 경 험한 불안, 좌절 등에 공감해 주고 내담자 내면의 질서와 힘의 발휘를 기다려 주는 작업을 하며 자신의 어려움을 말로 표현 하는데 한계가 있어 언어에 크게 의존 없이 내면세계를 드러 내며 치유가 행해지는 모래놀이치료를 실시하였다.

\section{연구의 타당성과 신뢰성}

본 연구는 연구의 타당성과 신뢰성을 확보하기 위해 다음과 같은 노력을 하였다. 첫째, 내담자의 치료과정을 탐색하기 위 하여 모래상자 사진, 모래놀이치료 전문가이면서 융분석가인 수퍼바이저의 수퍼비젼 내용을 활용하였다. 수퍼바이져의 지 도감독 내용은 내담자의 심리검사와 모래상자에 대한 분석과 해석에 관한 것이었다. 둘째, 분석심리학과 모래놀이치료 문 헌과의 접목을 통하여 치료과정에서 펼쳐지는 내용의 주제, 내담자의 심리와 실제 생활에서의 변화과정을 학문적으로 탐 색하였다. 이런 노력은 해석적 타당성과 이론적 타당성을 확 보하고 위함이다(J. K. Lee, 2006). 본 연구의 연구자와 수퍼바 이저는 현장에서 장기간 모래놀이치료와 연구에 종사한 자들 로 관찰의 안정성으로 본 연구의 신뢰도가 확보될 수 있을 것 으로 사료된다(J. K. Lee, 2006).

\section{Results}

\section{사전 심리검사}

내담자가 보고한 YSR에서 내재화 문제는 64T, 외현화 문제는
42T이고, 총 행동문제는 54T이고, 모가 보고한 $\mathrm{K}-\mathrm{CBCL}$ 에서 내재화 문제는 66T, 외현화 문제는 47T이고, 총 행동문제는 58T이다(Table 1). Oh 등(2010a, 2010b)은 문제행동증후군 척 도 점수가 64T (92\%ile)점 이상이면 ‘임상범위’로 보는데, 이런 관점에서 내담자와 모의 보고에서 내재화 문제는 임상적 수준 이다. 또한 소척도에서 모가 보고한 불안/우울, 신체증상, 사 고문제가 임상범위에 있다. Diagnostic \& Statistical Manual of Mental Disorders (DSM) 진단척도 중 내담자와 모가 보고한 정 서문제가 70T (98\%ile)로 임상범위에 있다.

MMPI-A의 경우, 임상척도에서 Hypochondriasis ( $\mathrm{Hs}$, 건강 염려증)는 다양한 내재화 문제와 이로 인한 신체적 문제의 호 소를 의미하는데 높은 편이고, Psychasthenia $(\mathrm{Pt}$, 강박증)는 주 의집중의 문제, 불안과 긴장, 불행감과 정서적 고통을 의미하 는데 매우 높은 편이며, Social introversion ( $\mathrm{Si}$, 내향성)은 사회 적 내향성, 소심함, 자존감의 부족을 의미하는데 이런 특성이 높은 편이다(Table 2). 내용척도에서는 불안, 강박, 기태적 정 신상태, 분노, 사회적 불편감이 높은 편이다(Table 3). 보충척 도에서 불안과 부정적 정서성이 높은 편이다(Table 4). 사전 객 관 심리검사에서 불안, 우울이 임상범위이고, 걱정, 불안, 부정 적 정서성이 높아 내담자의 주호소 문제인 정서문제가 그대로 드러나고 있다.

투사 심리검사 중 첫 번째, $\mathrm{HTP}$ 의 집은 나무로 지어진 몇 십 년 된 것이고, 혼자 살며 그냥 분위기가 없다. 행복한 때는 집을 꾸몄을 때이고, 불행한 때는 이웃이 갔을 때인데 오래된 마을이어서 이 집만 남았다. 소원은 다시 이웃이 생기는 것이 고, 집은 보면 외로운데 나중에 철거된다. 나무는 건강한 단풍 나무로 몇 백년정도 되었고, 하늘이 멋있다는 생각을 하고 있 다. 걱정하는 것은 자기가 죽을 때, 그냥 죽는다는 생각이 걱정 된다. 나무의 마음을 잘 알아주는 대상은 휽이고, 주변에 풀들 이 있고, 나무의 소원은 친구가 많게 더 많은 나무가 심어지는 것이다. 남자는 16 세 친구로 광장에서 누구를 기다리는데 누 구인지는 모르겠고 기다리는 사람이 빨리 왔으면 좋겠다. 날 씨가 추워서 추울 것 같다. 필요한 것은 앉아서 쉴 곳이고, 친 구를 못 만나 그냥 집으로 돌아가 마음이 슬플 것 같다. 여자는 서른 몇 살 정도인데 피곤해 침대에 누워 집에서 쉬며 좋아하 고 있다. 먹으면 시원할 물 한잔이 필요하고 피곤하지 않았으 면 한다. 두 번째, 가족화에서 동생은 뭐 해달라고 하고, 나는 소파에서 핸드폰 보고, 아빠와 엄마는 동생이 해달라는 걸 들 어주고 있다. 안 좋은 점으로 동생은 너무 시끄럽고, 나는 너무 조용하며, 아빠는 나한테 말이 너무 많아 대부분 좋지만 상황 에 따라 어떤 때는 싫으며, 엄마는 짜증을 많이 낸다. 세 번째, 
Table 1

The T Scores of the YSR and the CBCL 6-18

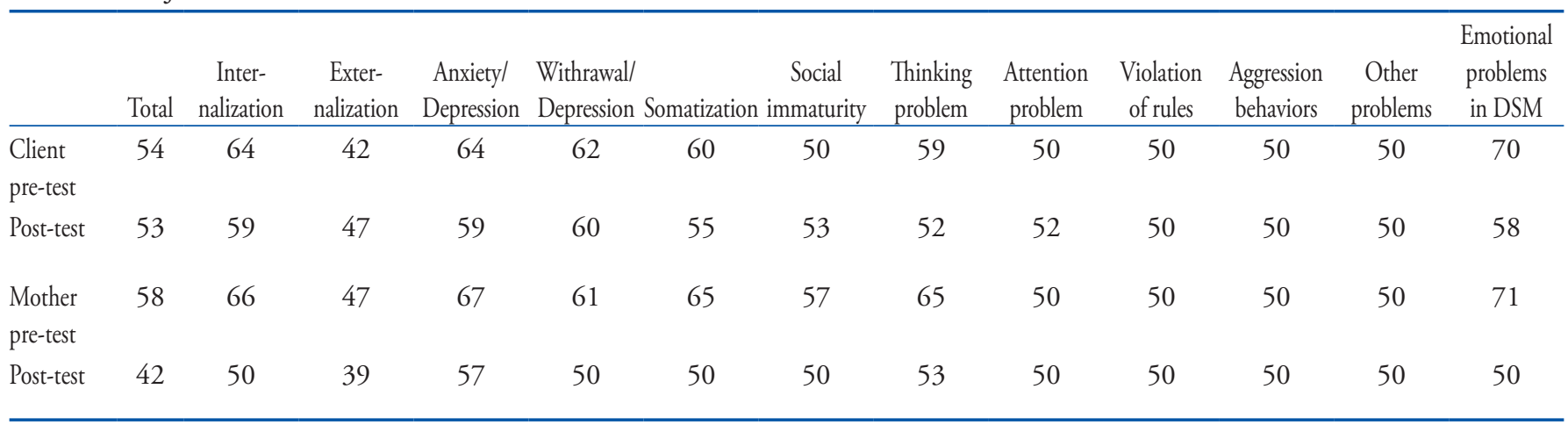

Note. According to $\mathrm{Oh}$ 등 $(2010 \mathrm{a}, 2010 \mathrm{~b})$, for the total, internalization \& externalization, above 64T (92\%ile): Clinical range, above 60T (84\%ile) under 64T (92\%ile): Subclinical range. For the symptom subscales \& DSM, above 70T (98\%ile): Clinical range, above 65T (93\%ile) under $70 \mathrm{~T}$ (98\%ile): Subclinical range.

Table 2

The Pre-and Post-T Scores of Validity Scales and Clinical Scales in MMPI-A

\begin{tabular}{cccccccccccccc}
\hline & $\mathrm{L}$ & $\mathrm{F}$ & $\mathrm{K}$ & $\mathrm{Hs}$ & $\mathrm{D}$ & $\mathrm{Hy}$ & $\mathrm{Pd}$ & $\mathrm{Mf}$ & $\mathrm{Pa}$ & $\mathrm{Pt}$ & $\mathrm{Sc}$ & $\mathrm{Ma}$ & $\mathrm{Si}$ \\
\hline Pre-test & 43 & 50 & 34 & 70 & 60 & 57 & 49 & 63 & 60 & 76 & 60 & 52 & 65 \\
Post-test & 39 & 38 & 47 & 39 & 42 & 47 & 39 & 48 & 52 & 48 & 47 & 54 & 49 \\
\hline
\end{tabular}

Table 3

The Pre-and Post-T Scores of Content Scales

\begin{tabular}{cccccccccccccccc}
\hline & A-anx & A-obs & A-dep & A-hea & A-aln & A-biz & A-ang & A-cyn & A-con & A-lse & A-las & A-sod & A-fam & A-sch & A-trt \\
\hline Pre-test & 86 & 68 & 63 & 63 & 52 & 69 & 67 & 58 & 52 & 66 & 48 & 53 & 40 & 49 & 53 \\
Post-test & 63 & 57 & 50 & 37 & 45 & 43 & 53 & 52 & 40 & 57 & 45 & 47 & 36 & 52 & 46 \\
\hline
\end{tabular}

Table 4

The Pre-and Post-T Scores of Supplementary Scales and Personality Psychopathology 5 in MMPI-A

\begin{tabular}{ccccccccccccc}
\hline & MAC-R & ACK & PRO & IMM & A & R & AGGR & PSYC & DISC & NEGE & INTR \\
\hline Pre-test & 45 & 45 & 41 & 48 & 70 & 43 & 57 & 64 & 39 & 70 & 45 \\
Post-test & 49 & 40 & 47 & 50 & 63 & 43 & 54 & 42 & 39 & 66 & 42 \\
\hline
\end{tabular}

학교화는 수업후 쉬는 시간에 4-5명 정도가 다 같이 모여 이야 기하는 것이다. 쓸데없는 이야기로 어떤 내용인지는 모르겠 고 나는 반에서 두루두루 친하지만 안 친한 애들도 많다. 마지 막으로 SCT 검사 문항 중 내담자의 어려움과 관련이 높은 문 항만을 보면, “사람들이 나를 피할 때 많이 슬프다.", "나의 좋 은 점은 별로 없다.", "나에게 가장 문제되는 것은 성격이다.", "나에게 어려운 일이 생겼을 때 이겨내려고 노력한다.", "나의 외모는 나쁘다.”, “살아오면서 가장 기뺐던 일은 친구가 많아 졌을 때, 살아오면서 가장 슬펐던 일은 동생 수술, 원하던 일 이 잘 안되었을 때 괴롭다.”로 응답하였다. 사전 투사 심리검
사에서 내담자는 불안하고, 허전하며, 외롭고, 죽음을 걱정하 며, 좌절스러워하고 친구가 많기를 소원한다. 실제로 내담자 는 $180 \mathrm{~cm}$ 가까운 키에 준수한 외모를 가지고 있지만 자신의 외모에 대해서도 부정적이고 가족과도 멀리 있다.

\section{모래상자 및 실생활에서의 변화}

모래놀이치료 총 33회기에서 모래상자 내용의 주제를 고려하 여 치료과정을 상담초기, 상담중기, 상담말기로 구분해 내담 자가 지은 모래상자의 제목과 말한 내용을 서술한다. 모래놀 
이치료 과정은 하나의 여정으로 치료과정 전체의 흐름을 파악 하기 위해 치료과정 전체를 회기별로 제시한다. 모래놀이치료 과정의 단계 및 주제를 간략하게 정리하면 Table 5와 같다.

\section{상담초기: 공허감과 퇴행}

상담초기는 1 회기 2회기(공허감과 퇴행)이다. 1회기 첫 번째 상자 1-1은 피사의 탑, 등대, 성 등 가로로 3건물, 세로로 5건물 을 줄지어 놓아 사각형 모양이다. 정중앙에 피사의 탑이 있다. 내가 좋아하는 것, 멋있어 보이는 것을 놓았다. 가장 멋진 것은 피사의 탑이고, 그다음은 콜로세움이다. 집들은 생길 때부터 모두 텅 비어 있는데 사는 것이 아니고 보여주는 것이다. 오른 편 모래에 손바닥 자국을 남긴다. 1주일에 2-3번은 잠들기 어 려워 2 시간 정도 지나 잠이 든다. 평소 학원에서 11 시에 오고 어제는 2시까지 공부를 했다. 두 번째 상자 1-2는 '화산'으로 모래에 밀랍을 넣어 모양 만들기가 수월한 델타샌드를 뭉치다 가 체에 모래를 넣어 꼭꼭 누르고 체질을 한다. 중앙에 모래를 쌓는다. 화산은 평화로워 폭발하고 싶은데 참는다. 참는 이유 는 사람들, 주변 인물들 때문으로 폭발하면 주변이 힘들어지 기 때문이다. 밀대와 수저를 꽂아 서서히 화산을 부순다. 2회 기 첫 번째 상자 2-1에서 델타샌드를 체질하고 여러 모양을 찍 는다. 운동은 안 좋아한다. 학원에만 있는다. 웬만하면 불평없 이 하고 싶다. 이제 고등학교에 가니 공부 안하면 문제가 생길 것 같다. 30 센티 자로 오른편에서 왼편으로 모래 반절을 깨끗 이 밀었다 다시 모래 전체를 손으로 흩뜨린다.

두 번째 상자 2-2 '파도'에서는 무릎을 세워 앉은 자세로 양
손으로 모래를 만진다. 오른편 앞 쪽에 작은 모래더미를 만들 어 손으로 다독이는데 모래더미가 모의 가슴 같다. 모래를 다 펴 놓는다. 파도는 거칠지 않다. 옆 정리장의 벌린 주먹만한 크 기의 진짜 같은 가슴 소품 하나를 집어 만진다.

\section{상담중기: 투쟁}

상담중기는 3회기 27회기(투쟁)인데, 상담중기 I은 3회기 13 회기(치열한 전쟁), 상담중기 II는 14회기 27회기(전쟁의 끝)이다. 먼저, 상담중기 I은 3 회기 13 회기(치열한 전쟁)이 다. 3회기 첫 번째 상자 3-1은 '사막여행'으로 오른편 앞 낙타 위 군인은 서로 친구로 한 달 정도의 힘들었지만 좋았던 이집 트 여행이야기를 하며 집으로 간다. 파란 바닥은 오아시스이 다. 두 번째 상자 3-2 '악당들의 싸움'에서는 즐겁게 맞춘 두 개 의 바이오니클 로봇을 상자 양편으로 놓는다. 자기가 더 세게 보이려고 악당 둘이서 싸우는데 결국 둘 다 아무 이득 없이 진 다. 막으려고 여러 나라에서 비행기를 보냈는데 다 넘어졌다 며 군용 트럭, 비행기 등을 모래에 비스듬히 놓는다. 모의 보고 에 의하면, 평상시 자는 모습은 바로 눕거나 편한 자세로 자는 경우는 거의 없고 앉아서 엎드린 자세나 잔뜩 웅크리고 자는 편이다. 아주 가끔 무섭다고 자다 깨서 거실로 나오기도 한다.

4회기 첫 번째 상자 4-1 젖은 상자에서 오른편쪽에 세로 로 두 개의 성을 빼놓고 성을 슬슬 부순다. 오른편 앞쪽을 산 처럼 만들어 놓는다. 자동차와 비행기를 찍어 놓았다가 다 부 순다. 두 번째 모래상자 4-2 '탑’에서는 다 뭉쳐 버리고 싶다 며 30센티 자로 중앙에 모래를 모은다. 중앙에 커다란 산 모

Table 5

The Stages, Themes and Life Reports of Sandplay Therapy Process

\begin{tabular}{|c|c|c|c|c|}
\hline \multicolumn{3}{|c|}{ Therapy process } & Theme & Life report \\
\hline Intermediate phase & Struggle & $\begin{array}{l}3-13 s \\
\text { Fierce wars }\end{array}$ & $\begin{array}{l}\text { Fights of villain } \\
\text { Building towers \& Mountains } \\
\text { Making bridges }\end{array}$ & $\begin{array}{l}\text { Sleep problems } \\
\text { Complaining about school } \\
\text { Mother heard the client's strong } \\
\text { Willpower from a class teacher }\end{array}$ \\
\hline & & $\begin{array}{l}14-27 s \\
\text { Ending wars }\end{array}$ & $\begin{array}{l}\text { Plunge } \\
\text { Expression of mess } \\
\text { Ending wars }\end{array}$ & $\begin{array}{l}\text { Enjoying basketball club } \\
\text { Participating school athletics competition } \\
\text { Participating footballgame }\end{array}$ \\
\hline Final phase & & $\begin{array}{l}28-33 s \\
\text { Active daily life }\end{array}$ & $\begin{array}{l}\text { Motorcycle race } \\
\text { Expression of strong masculinity } \\
\text { Making villages }\end{array}$ & $\begin{array}{l}\text { Studying by himself } \\
\text { Expecting high school life }\end{array}$ \\
\hline
\end{tabular}


양을 다독인다. 자꾸 쌓아 놓은 것을 누르며 높이 세운다. 사 람들이 만든 탑이다. 모의 보고에 의하면, 학교에서 학교폭력 이 발생했는데 적절하게 가해자를 벌하지 않아 내담자는 부 당하다며 화를 낸다. 5회기 첫 번째 상자 5-1에서는 치열한 전 쟁을 위해 작은 군인들을 두 팀으로 나눈다. 왼편이 더 강하 고 왼편이 오른편 지역을 뺏으려고 한다. 군인들이 쓰러진다. 싸움은 아직 끝나지 않았다. 흩뜨리며 모래 속에 든 군인들을 세운다. 왼편이 이길 것 같다. 모래상자 중앙에 양손바닥 자 국을 남긴다. 두 번째 상자 5-2에서 델타샌드로 탑을 만들었 다가 부순다. 정리장의 가슴하나를 집어 주무르다 바로 놓는 다. 모의 보고에 의하면, 내담자는 록음악 중 영국의 오아시 스 밴드 음악을 마니아 수준으로 즐겨 듣고 그런 자기 음악세 계를 걸과 보이그룹이나 좋아하는 친구들과 비교해 좀 자랑 스러워한다.

6회기는 ‘죽순’이다. 델타샌드를 힘차게 다 갈아엎고 손으 로 힘차게 주물러 철저히 모래를 다 섞는다. 손을 넣어 두꺼 비 집처럼 만들어 놓고 군인을 넣다가 안을 더 판다. 군인들 이 지내는 곳이라며 뒤쪽을 뚫어 놓고 군인들을 뒤쪽에 세우 기도 한다. 어려운 점은 친구들이랑 좋은 관계를 유지하는 것 인데 게네들은 자기 맘대로라며 애들이 많이 어린 것 같다고 한다. 학교는 폭력에 너무 제재가 없다는 등 학교에 대한 불 만을 토로한다. 군인들을 오른편 뒤로 모아 치우고, 중앙으 로 커다랗게 모래를 모으고 어슷, 어슷 모양을 남긴다. 7회기 첫 번째 상자 7-1에서 약간 젖어 있는 모래를 주무르고 만지 는 모습이 힘차고 역동적이다. 성을 만들었다가 부수는 작업 을 반복한다. 두 번째 상자 7-2 '파도'에서 하트틀로 하트를 만 든다. 학교에서 목요일과 금요일에 서울에 가는데 요즘 위험 하니 걱정이 된다. 조에 미션을 주고 흩어졌다가 모인다. 부 당한 교사들 이야기를 하며 계속 체질을 하다가 눌러 놓는다. 파도는 잔잔하다.

8회기 첫 번째 상자 8-1 '군대'에서 병정의 모습을 하나하 나 보며 왼편 뒤와 오른편 앞에 세운다. 오른편 앞의 애들이 공격을 했으나 생각보다 왼편 뒤가 세서 지고 있다. 왼편 뒤 에서 점점 병정들이 내려오는데 땅을 차지하는 전쟁이다. 어 느 쪽도 못 이기고 계속 싸우기만 한다. 두 번째 상자 8-2에서 모래덩이를 단단히 해 주변을 칼로 깎아 놓는다. 4 개의 산 같 은 모양이 있다. 9회기 첫 번째 상자 9-1에서 약간 젖은 모래 를 양주먹으로 쥐고 주무른다. 오른편에 세로로 덩이를 모아 2개의 구멍을 내 '강의 다리'라고 한다. 두 번째 상자 9-2에서 델타샌드로 왼편쪽에 사선으로 다리 모양을 만들어 구멍을 내고 오른편쪽에 작게 다리를 만들었다가 부순다. 3 개의 기
둥을 만들고 다른 덩이를 만들어 위로 얹기도 하며 다리를 만 들어 놓는다. 모는 학교상담 주간에 담임교사를 만나 내담자 가 욕심이 없고 심약해 걱정이라고 하자 교사는 원하는 것을 관철시키려 하기도 하고 멘탈이 강한 편이라고 해 아들의 멘 탈이 강하다는 말은 처음 듣는다.

10 회기 첫 번째 상자 10-1에서 양손을 벌려 나비 모양처럼 모래를 휘젓는다. 한동안 주먹을 쥐어 모래를 흘러내리게 하 며 모래를 바라본다. 양손 주먹으로 모래를 주무른다. 양손을 어깨 높이로 들고 손에서 모래가 흘러내리게 한다. 전교 20위 아니 10 위 안에 들어가는 것이 목표이다. 요즘 달라진 점은 예전에는 딴 생각, 멍 때렸는데 이런 시간이 적어진 것이다. 두 번째 상자 10-2 ‘웃는 사람'에서 델타샌드로 체질을 하며 2 박 3일로 극기훈련 캠프를 지리산으로 가 조를 짰는데 나랑 친구를 떼어 놓았다고 한다. 체력도 떨어지고 머리를 쓰는 것 은 해 보겠는데 몸 쓰는 것은 자신이 없다. 만든 상에 자꾸 모 래를 붙이기도 하며 쓸어 올린다. 캠프에 대해 선생님께 전화 를 해야겠다. 모래상자 사람은 나이가 많은 남자이고, 어딘가 를 보고 웃고 있으며 속마음은 나쁘지 않다. 11회기에서 캠핑 건 전화는 어떻게 되었는지 묻자, 안 했다며 모가 전화해서란 다. 교사가 모에게는 거짓말을 했다며, 키 순으로 했고 짐을 들 수 있는 순서대로 조를 정했다고 했단다. "막상 가면, 재미 있겠죠.” 한다. 상자 '산들'에서 모래전부를 모아 큰 덩이를 만 든다. 두 번째 덩이를 손으로 잘 다듬는다. 옆 정리장에 놓인 젖가슴을 튕긴다.

12 회기 델타샌드에서 모래를 양쪽에 세우고 이 사이에 연 결 덩이를 올려놓고 '다리’라고 한다. 뭔가 생활 속에서 부당한 것에 대한 이야기가 이어진다. 반복적으로 모래상자에 다리를 만들어 놓는다. 모의 보고에 의하면, 야영을 가 전화해 정신과 육체적으로 너무 힘들다며 울먹였는데 막상 와서는 생각보다 컨디션도 좋고 기분도 나쁘지 않았다고 한다. 치료자의 조언 에 따라 요즘 아버지랑 운동을 하는데 학교에서 동아리 활동 을 농구부로 바꿔볼까 한다. 요즘 모에게 틱틱거리고, 단 음식 을 좋아해 부모가 설탕 중독이라고 놀리자 놀랄 정도로 토라 진다. 모는 보통 중 2 병이 중 3 에 온 것 같은 느낌이란다. 13 회 기에 델타샌드를 만지며 전교에서 제일 안 좋은 애와 같은 모 둠이 된 것과 캠프에서 내가 징징댔다고 교사들이 이야기했다 며 교사들과 관계만 나빠지고 얻은 것도 없다고 한다. 중앙에 커다란 덩이를 뭉쳤다가 양손을 아주 활발하고 자연스럽게 움 직여 모래를 흩뜨린다. 빨리 졸업해 인근 도시의 N고등학교에 가고 싶다. 모의 보고에 의하면, 동아리 활동으로 농구를 신청 해 친구들이랑 뛰고 재미있었다고 하고 땀을 많이 흘리고 학 
원에 가 늦게 왔는데 오히려 덜 피곤해 한다.

상담중기 II는 14 회기 27회기(전쟁의 끝)이다. 14회기 첫 번째 상자 14-1에서 델타샌드를 눈덩이처럼 만들어 굴린다. 학교의 문제아들과 배려가 없는 교사들 이야기를 한다. 30센 티 자를 사용해 모래를 네모 상자 안에 네모 모양으로 모은다. 두 번째 상자 14-2는 ‘호수’인데 젖은 상자에 물 한 병을 붓고 오른편 뒤와 아래로 물길을 낸다. 상자 모래 전체를 다 휘젓는 다. 계속 모래를 주무른다. 중앙에 모래를 모으고 물을 한 병 더 붓자 물이 터져 흐른다. “되게 좋다.”며 양 주먹으로 모래를 주무른다. 중앙을 갈라 아래로 물이 흐르게 한다. 강, 넓은 강 이다. 모의 보고에 의하면, 농구를 열심히 해서 땀에 흠뻑 젖어 온다. 예전보다 훨씬 잘 잔다. 학급 야영도 엄청 재밌었다며 흥 분해서 이야기한다. 15회기는 델타샌드에서 커다란 주걱으로 모래를 민다. 체 속에 모래를 높이 올려 주걱으로 윗부분을 두 드렸다 오른편 뒤에 빼 놓았다가 부순다. "그냥 높이 쌓고 싶 다."며 오른편 뒤에서 계속 모래를 쌓아 올리는데 무너진다. 고등학생이 안 되면 좋겠다. 공부를 많이 해야하고 진학 걱정, 취업 걱정을 해야 한다. 밤에 잠을 자는 것이 많이 나아졌다. 다 치우고 체질을 계속한다. 모의 보고에 의하면, 추석에 친척 들이 모이는 $\mathrm{L}$ 시를 갔는데 평소와 달리 책을 가져가서 고교생 사촌누나들이랑 독서실에서 공부를 하고 오기도 한다. 친척들 과 노래방에서 즐거운 시간을 보낸다. 학교 체육대회에서 행 하는 기마전이랑 많이 먹기 대회에 나간다고 해 평소 전혀 그 런 걸 하는 아이가 아니어 의아해 한다.

16 회기는 '사막'이다. 중앙에서 도톰하게 덩이를 다독인다. 고무주걱으로 모래전체를 쓴다. 사막이고, 위는 바다이다. 평 화롭다. 친한 친구인 낙타 두 마리가 앞으로 계속, 계속 가는데 언젠가 어디에 도착한다. 가는 여정이 힘드나 서로 돌볼 거다. 치료실 바닥에 가구소품들로 집 내부와 외부를 천천히 만들어 놓고 진짜 좋다며 이 집, 가정 분위기는 화목하다고 한다. 17 회기 첫 번째 상자 17-1에서 고무주걱으로 모래를 뒤집는다. 계속 두 개의 산 같은 모양을 손으로 다듬다가 다 부순다. 두 번째 상자 17-2 ‘추락'에서 비행기들을 모래에 부분적으로 감 춘다. 왼편에 다른 비행기를 세운다. 폭풍, 자연재해로 다 추락 했는데 조종사는 다 탈출한다. 모의 보고에 의하면, 이번 주에 드디어 4 일간의 시험이 끝나서 지금 너무 좋아한다고 한다. 요 근래 가장 행복하다고 탄성을 지르면서 집안을 활보한다. 18 회기에는 델타샌드를 커다란 컵에 담아 단단히 눌러 모양을 빼 놓는다. 뺀 모양의 앞 쪽에서 엄지로 모래를 부순다. 슬슬 덩어리를 떼어 부순다. 모의 보고에 의하면, 요즘 매주 부랑 농 구를 하고 잠을 잘 못 잤다는 말은 안한다. 19회기에는 델타샌
드로 중앙에 커다랗게 남근모양으로 모래를 올린다. 눈덩이처 럼 크게 덩이를 만든다. 애들을 교사들이 잘 못 다루는 이야기 를 하며 학교에 대한 불만을 폭발적으로 토로한다. 요즘은 빨 리 졸업하고 싶다. 졸업이 싫었는데 지금은 아니다. 이번 시험 을 나는 최고 잘 봤다. 한 친구와 엇나간 것이 1 년 계속되고 있 다. 친구이야기를 엄마에게도 못하고 말 할 사람이 없다고 한 다. 모의 보고에 의하면, 반 대항 남학생 축구경기에서 주전을 정하는데 자기도 끼워 달라고 해 전 후반 다 뛰었다. 첫 경기는 아쉽게 졌는데 둘째 날 경기는 내담자 반이 이겨 자기 때문에 질까봐 걱정을 많이 하더니 이겨서 다행이라며 기뻐한다. 이 제는 예전처럼 소극적으로 지내진 않는다고 한단다.

20 회기의 '난장판'에서 델타샌드를 핑크계열 큰 컵에 담는 다. 내신이 전교 9등으로 생각보다 좋다고 한다. 상자 중앙 부 분쯤에 모래를 판판히 한다. 요즘 잠은 괜찮다. 모래에 박았던 비행기 주변을 쓰다듬다가 비행기를 꺼낸다. 트럼프가 대통 령이 된 이야기, 박근혜대통령 이야기를 한다. 비행기가 날아 가고 있다. 체질을 해 나온 모래를 만지다가 체를 정리한다. 정 리장에 돌려놓은 비행기를 다시 가져다 던져 놓는다. 모의 보 고에 의하면, 친구들이랑 농구를 하는데 한 친구가 개인적으 로 불러 지시를 했는데 내담자는 알았다고 하며 못하면서 나 서는 것이 좋다고 한다. 축구를 하는데 여자애들이 웃어도 괜 찮아 해 그동안 부끄러워하지 말고 마음 내려놓으라고 그렇게 이야기를 해도 안 되었는데 상담 받으며 이것이 되었다고 한 다. 21회기 첫 번째 상자 21-1에서 델타샌드를 작은 밀대로 오 른편 뒤쪽을 네모나게 민다. 좀더 큰 밀대로 더 큰 네모 모양으 로 밀어 놓고 밀대 뒤로 구멍자국을 숭숭 내 놓는다. 두 번째 상자 21-2 '바닷가'에서는 물을 한 병 붓고 오른손으로 모래를 비비고 쓰는 작업에 몰두한다. 한 병 더 물을 붓고 상자 앞쪽에 서 무릎을 세우고 앉은 자세로 모래를 철썩이는데 몰두한다. 계절은 가을이고, 바다가 잔잔하며 분위기는 좋다고 한다. 모 의 보고에 의하면, 원하던 고등학교 면접을 긴장 없이 잘 보았 고, 자기소개서도 다른 사람 도움 없이 잘 써 합격은 거의 확정 적이라고 한다. 22회기는 '절벽'으로 젖은 상자 앞에서 모래를 양손으로 주무르며 국어, 영어는 괜찮은데 수학이 초등 3학년 부터 어려웠다며 고등학교에 가서 상위권에 못 들까 봐 걱정 이란다. 물을 한 병 더 붓는다. 물을 철썩거려 모래가 물에 씻 겨 내리는 것을 찬찬히 본다. 모래더미를 가까이 보면서 엄지 와 중지로 모래를 다독이고 더미 끝 뾰쪽한 부분을 섬세히 만 진다. 바닷가이고, 사람은 없고 웅장하다. 모의 보고에 의하면, 원하던 고등학교의 합격통지서를 받았고 반 배치고사를 준비 한다. 23회기에 치료자가 합격을 축하한다고 하자 "이제 시작 
이다.”라고 한다. 첫 번째 상자 23-1에서 물 한 병을 쏟아 양손 으로 모래를 주무른다. 모래를 중앙으로 모은다. 모래와 물을 철썩거린다. 주먹질을 해 모래를 흩뜨린다. 코 모양과 눈 모양 을 만들었다가 모래와 물을 철썩인다. 두 번째 상자 23-2 '벌 판'에서 델타샌드를 고무주걱으로 만진다. 그냥 크는 것이 싫 다. 짜증난다. 이대로 있었으면 좋겠다. 오른편 뒤쪽의 바닥을 드러낸다. 늘 심난한데 심난할 때 놀면 된다. 그렇게 심난하지 않다. 상자는 봄이나 가을인데 사람은 없다. 모의 보고에 의하 면, 본인은 새 것을 갖고 싶은데 아빠가 중고 노트북을 구하려 하니 말을 못한다. 오늘은 시험 끝나고 친구들이랑 놀러갔고 시험을 잘 본 것은 아닌데도 싱글벙글 한다. 24회기에는 델타 샌드를 네 가지 모양이 있는 틀에 넣는다. 양손으로 모래를 비 비기도 한다. 체질을 한다. 25 회기 '전투'에서 오른편 앞에 오 른손을 펴 놓았다가 모래를 주무른다. 내담자 편인 기사와 배 트맨의 싸움인데 배트맨이 공격을 시작하고 기사가 나뒹군다. 힘이 막상막하여서 계속 싸울 것 같다. 말 탄 기사가 배트맨을 누른다. 모의 보고에 의하면, 전화하는 것을 보면 친구들 사이 에서도 미안하다고 많이 하는 것 같다고 한다. 변한 것이 있는 데 상담 전에는 집에서 여름에도 옷을 갖춰 입고 단추도 잠그 고 있었는데 지금은 팬티만 입고 돌아다닌다는 것이다.

26회기 첫 번째 상자 26-1 '친구들'에서 추장집인데 친한 친 구들이 놀러와 모닥불에서 재미있는 이야기를 한다. 오른편 뒤 에서 주먹으로 모래를 내린다. 분위기는 화목하다. 파란 바닥은 오아시스이다. 왼편 앞에 오른손바닥 자국을 낸다. 두 번째 상 자 26-2에서 비행기 틀에 모래를 넣고 누른다. 힘들까봐 고등학 교 가는 것이 그냥 싫다. 왼편 뒤에 비행기 모형을 빼 놓는다. 모 의 보고에 의하면, 지난주 상담을 마치고 왔는데 아주 밝았다 고 한다. 벌써부터 취업걱정도 하지만 고등학교에 가면 임원을 해 보고 싶다고 한다. 27회기 첫 번째 상자 27-1 '전쟁이 끝난 후' 에서 양손을 왼편 뒤를 사선으로 향해 모래에 깊이 넣고 있다. 전쟁이 끝나 몇 십 년 후 인간이 떠나가서 동물들이 살고 풀도 산다. 두 번째 상자 27-2에서 물을 2병 붓고 모래를 주먹으로 쥔 다. 3 병째 물을 붓고 양손을 펴 손가락으로 뒤와 양쪽에서 찰랑 거린다. 모의 보고에 의하면, 고등학교 영어, 수학도 스스로 알 아서 하고 학교 부담은 점점 덜 느끼는 것 같다고 한다.

\section{상담말기: 활기찬 일상}

상담말기는 28 회기 33회기(활기찬 일상)이다. 28 회기는 '마 을'로 눈 오는 날 여자가 주인인 노란차가 눈길에 빠져 철선으 로 빼 주는 것이다. 잘 도와주고 마을은 평화롭다. 작은 소녀를
가져와 모와 손을 잡게 해 놓고 “끝." 한다. "집에 가는 길이었 다.”며 집은 맨 왼편의 아파트로 왼편으로 돌아가 금방 간다. 모의 보고에 의하면, 이번 주에 3 박 4 일 일정의 고등학교 예비 학교에서 돌아와 재밌었다며 친구들도 십여 명 넘게 사귀었다 고 한다. 29회기는 '오토바이 경주'로 이집트에서 경주를 하는 데 표범과 아래 동물은 무엇인지 모르는데 구경한다. 왼편 앞 은 피니쉬라인이다. 모의 보고에 의하면, 며칠 전 다니던 공부 방을 그만 두고 혼자 공부한다며 계획표를 보여주고 고등학교 생활이 기대된다고 한다.

30 회기에는 오른손을 펴 모래 깊이 넣고는 모래를 만진다. 모래를 양손으로 모아 재미난 듯 만진다. 오른손 주먹으로 모 래를 내린다. 양쪽에 윗눈썹 같은 모습을 만들고 다시 더 긴 윗 눈썹 모양을 양쪽에서 중지로 만든다. 다시 모래를 주무르다 가 의식을 다 치른 듯 치료자를 본다. 모의 보고에 의하면, 졸 업식이 끝난 직후 스스로 다니던 학원도 정리하고 휴대폰도 안 가지고 독서실에 다닌다. 31회기 첫 번째 상자 31-1에서 나 비 모양처럼 모래를 만진다. 오른손으로 모래를 판판히 한다. 오른손을 모래 속에 깊이 넣어 모래로 다 덮고 살살 움직여 본 다. 두 번째 상자 31-2에서 고무주걱으로 힘차게 모래를 모으 고 몸체를 단단히 눌러 다독여 남근 모양이 더 크게 모래를 붙 인다. 앞면을 주걱으로 깎고 부드럽게 손으로 표면을 만진다. 높이가 38센티 정도이다. 32회기 첫 번째 상자 32-1에서 양쪽 에서 양손으로 모래를 만진다. 오른편 뒤에 동그랗게 바닥을 드러내고 내부를 오른손 중지로 깨끗이 한다. 오른손으로 모 래를 밀어 드러난 바닥을 덮는다. 다시 모래로 손등을 덮고 들 썩여 본다. 두 번째 모래상자 32-2에서 중앙에 덩이를 모은다. 모래를 붙여 계속 원을 크게 하고 주변에 원을 굴려 크기를 키 우고 주변을 매끄럽게 하는 작업을 한다. 덩이를 모래 위에 굴 리다가 덩이가 조각조각 떨어지자 부셔버린다.

최종회기, 33회기는 '마을'로 소품을 심 없이 쏟아 내는 모 습이다. 평범한 마을이다. 긴 남자와 흑인 남자는 일을 끝내고 집으로 가는 것이다. 입을 가린 여자는 옆의 남자와의 약속에 늦은 거다. 왼편 뒤 사람은 친구로 왼편 앞 가방을 맨 아이에게 뭔가 필요해서 전화하는 것이다. 위쪽의 교회 같은 건물은 학 교이고, 앞의 것은 교회다. 분수대는 공원이고 학교가 끝난 시 간으로 모여서 놀고 있다. 굴은 다른 마을에서 오는 터널이다. 소방서는 있으면 괜찮을 것 같다.

\section{사후 심리검사}

사전에 임상수준이었던 YSR의 내재화 문제는 59T로 많이 완 
화되었고, $\mathrm{K}-\mathrm{CBCL}$ 의 내재화 문제 역시 $50 \mathrm{~T}$ 로 사전에 비해 문 제가 많이 완화되었으며, DSM 진단척도 중 정서문제도 많이 완화되었다(Table 1). 사후검사 MMPI-A의 경우, 임상척도, 내 용척도와 보충척도에서 점수가 낮아졌고, 성격병리 5 인 중 부 정적 정서성은 여전히 높은 편에 머물고 있다(Table 4).

투사 심리검사 중 첫 번째, HTP의 집은 나무로 된 오래된 것으로 우리가족이 화목하게 살고 있다. 나무는 건강하고 오 래되었는데 행복한 때는 나뭇잎이 생겼을 때이고, 불행한 때 는 잎이 떨어졌을 때이다. 나무는 나중에 집을 짓는 재료가 된 다. 처음 그린 사람은 남자로 멍 때리고 서 있고 친한 친구가 많으며 소원은 꿈을 이루는 것인데 그 꿈은 모르겠다. '여자는 저것이 무엇인가?'하며 어떤 것을 보고 있고 친한 친구가 많 다. 두 번째, 가족화는 동생 졸업식에 사진을 찍고 있는데 화목 해 보인다. 세 번째, 학교화는 수업이 막 끝난 상황으로 이야기 하면서 있다. 마지막으로 SCT 검사 문항 중 사전검사와의 비 교를 위해 사전과 같은 문항만을 보면, "사람들이 나를 피할 때 나는 슬프다.", "나의 좋은 점은 많다.", "나에게 가장 문제 되는 것은 게으르다는 것이다.", "나에게 어려운 일이 생겼을 때 극복해내야 한다.", "나의 외모는 보통이다.", "살아오면서 가장 기뺐던 일은 매우 많다.”, “살아오면서 가장 슬펐던 일은 너무 많다.", "원하던 일이 잘 안되었을 때 화가 난다.”로 응답 하였다. 전체적으로 투사 심리검사를 보면, 혼자 살던 집에서 가족이 살게 되고, 사람이 의젓하고 성숙해졌으며, 가족이 함 께 있고, 학교에서도 친구들과 함께 있다. 친한 친구도 많아지 고 자신이 긍정적인 부분이 많음을 자각하게 된 모습이다.

\section{Discussion}

본 연구는 부모하고 14 개월 터울의 주산기 어려움 때문에 뇌 병변으로 사지마비가 되어 휠체어 생활을 하는 여동생과 생활 하는 중학교 3 학년에 재학 중인 남학생의 모래놀이치료과정 을 Turner (2005)의 내용주제에 초점을 두고 분석심리학과 모 래놀이치료 이론의 관점에서 탐색하였다. 내담자는 $180 \mathrm{~cm}$ 가 까운 키에 준수한 외모를 가지고 있고 애늙은이라는 소리를 듣는 모범생이다. 학교에서 실시한 정신건강 검사에서 불안과 우울점수가 높았고, 밤에 불을 끄고 자지 못하며 잠드는데 어 려움이 커서 모에 의해 치료에 의뢰되었다. 청소년기 내담자 에게 언어에 크게 의존 없이 자신의 내면세계를 드러낼 수 있 는 모래놀이치료를 실시하였다.

총 33회기 모래놀이치료 과정을 모래상자 내용주제의 흐
름에 따라 상담초기, 상담중기, 상담말기로 구분해 본다. 먼 저, 상담초기는 1 회기 2회기(공허감과 퇴행)이다. 1 회기에 서 건물이 멋지라고 지어 놓았다는데 이는 내담자의 페르조나 로 보인다. 청소년기는 사회적 요구에 맞춰 적절한 페르조나 를 형성할 시기이다(Rhi, 2002). 그러나 건물이 생길 때부터 모 두 텅 비어 있고, 사는 것이 아니고 보여주는 것이라고 해 이는 내담자의 정서적인 공허와 연결되는 부분인 것 같다. 모래상 자 모습이 만다라상으로 굉장한 불안을 시사하는데(Grubbs, 2007), 네모로 균형을 맞춰서 질서와 규칙이 있어 보이나 답답 하고 경직되어 있다. 가장 멋진 건물이 '피사의 탑’이라고 하는 데 피사의 탑은 전쟁에서 승리한 것을 기념해 건축한 것으로 높이 솟은 탑은 남근을 상징한다(Ackroyd, 1997). 내담자는 심 리적으로 청소년에서 한 남성으로 성장하려면 견고한 남성성 을 지녀야 한다. 오른편 모래에 손바닥 자국을 남긴다. 모든 사 람의 손바닥은 독특해 손바닥 자국은 정체성과 관련이 있다 (Anderson, 2019; Flahive, 2012). 내담자가 외부로 보여지는 모 습만이 아닌 진정한 자신의 모습, 정체성을 찾아가는 여정이 필요함을 시사하는 상자이다. 1 회기 두 번째 상자에서는 화산 을 만들어 놓고 평화로워 폭발하고 싶은데 참고 있고 언젠가 는 폭발할 것이라고 한다. 내담자 내면에 폭발시키고 싶은 무 엇이 있는 것으로 이는 억압해온 다양한 욕구불만, 학업 스트 레스 등 일 수 있다.

2 회기 첫 번째 상자에서 유아기 아이들처럼 모래를 체질하 여 여러 모양을 만들며 “운동을 안 좋아한다.", “학원만 있는 다.", "웬만하면 불평 없이 하고 싶다.” 등 자신의 이야기를 하 는데 이는 심리적으로 유아기로 퇴행하여 내면의 작업을 하 는 모습이다. 여기서의 퇴행은 낮은 단계로 퇴화함을 의미하 지 않고 근원, 원형적인 모에게로의 회귀로(Rhi, 1987), 창조 적인 퇴행이다. 모래가 감각발달의 초기단계로 돌아가게 하 고 모래를 만지는 것이 개인의 촉각과 운동 이미지 그리고 원 형들을 활성화시킨 것이다(Manevsky, 2003). 또한 퇴행은 필 수적인 단계로 뒤따를 변화와 탄탄해질 인격에 대한 서곡으 로(Anderson, 2009) 치료자가 제공하는 자유롭고 보호된 공간 이 유아기의 정서와 경험으로 퇴행하게 해 준 것이다(Winter, 1999). 두 번째 상자에서는 작은 모래더미를 만들어 손으로 다 독이는데 모래더미가 모의 가슴 같다. 실제로 내담자는 정리 장의 실제 같은 가슴 소품을 집어 만지기도 한다. 모래를 다 펴 고 '파도'라며 거칠지 않다고 하는데 이로써 내담자가 바다에 와 있는 것을 알 수 있다. 바다는 무의식을 나타내 바다로 들어 가는 것은 무의식을 탐구하는 것을 상징한다(Ackroyd, 1997). 상담초기 내담자는 자신의 처지, 어려움을 표현하며 정체성을 
찾아가는 무의식의 여정의 시작을 알리고 있다.

두 번째, 상담중기는 3회기 27회기(투쟁)인데, 먼저 상담 중기 I은 3회기 13회기(치열한 전쟁)이다. 3 회기의 사막여행 은 힘들지만 오아시스와 식물 같은 자원이 있다. 두 번째 상자 에서 악당의 싸움이 원조가 와도 못 말릴 정도인데 이는 치열 한 내면의 갈등을 표현한 것이다. 4 회기 첫 번째 상자는 유아 기로 퇴행한 모습이고, 두 번째 상자는 매우 남근적이다. 탑은 다른 시각을 가질 필요성을 나타내며, 내담자가 추구하고 필 요한 남성성으로(Ronnberg, 2010) 한 회기에 두 개의 상자로 내담자 내면의 현 위치와 추구하고 필요한 모습을 표현하고 있다. 5 회기는 아무 소득이 없는 전쟁이다. 왼편은 무의식을 상징하는데(Ackroyd, 1997) 왼쪽에서 쳐들어오고 왼쪽이 강세 로 이에 압도되어 내담자는 우울하고 불안한 것 같다. 다시 탑 을 만들었다가 부순다. 정리장의 가슴소품을 집어 주무른다. 6 회기는 죽순으로 중심에서 형체가 나왔다. 죽순은 하루 동안 에 생장하는 것이 소나무가 30 년 동안 자라는 길이와 같을 정 도로 성장이 매우 빠르다고 하는데 죽순 역시 강한 남성성으 로의 성장을 시사한다. 7 회기에 다시 퇴행을 하고, 파도로 자 신의 갈등과 어려움을 표현한다. 8 회기에 땅을 차지하는 전쟁, 투쟁을 한다. 모래로 만든 형상이 삼각뿔 모양으로 피라미드 같기도 한데 피라미드는 재생과 관련이 있다(Cooper, 1978). 9 회기의 다리는 연결과 의사소통을 의미하는데(Miles, 2012), 다리로 연결하고 있다. 통과의례로 터널을 거치는 것 같기도 한데 내담자 내면에서의 연결, 통과 등이 이루어지고 있음을 알 수 있다. 모는 학교 담임교사에게서 내담자의 멘탈이 강하 다는 말을 듣는다. 10 회기의 웃는 사람은 내담자가 웃는 모습 으로 정체성을 확립해 가고 있는 듯 하다. 멍 때리는 시간이 적 어진다. 11 회기의 산들은 정신, 영적인 신을 만날 수 있는 곳 이다. 산은 변화와 여성의 변형적인 특성으로 고통, 죽음, 희생 과 무효화를 통해 재생, 소생, 불사로 이끄는 태모원형과 관련 이 있다(Schwerdtfeger, 2016). 산의 크고 작은 모양은 애착문제 와도 연결되어지는 부분이다. 12 회기에서 다시 여러 개의 다 리를 만드는데 이런 반복적인 표현을 통해 내담자는 내적으로 성장한다.

내담자가 반복적으로 표현하는 전쟁은 대극의 역동적인 긴장을 나타내는 반대 힘의 갈등을 말하며, 심리적으로 전쟁 은 성장, 발달, 변화, 변형과 연결될 수 있다(Porat \& Meltzer, 1998). 청소년의 모래상자에서 종종 보이는 투쟁과 전쟁은 청 소년기에 본능과 정반대의 긴장 사이에서 촉발된 갈등을 나 타내고 또한 의식과 무의식 간의 갈등을 나타낸다(Montecchi, 1999). 삶은, 특히 청소년기에서는 전쟁으로 여겨지는데, 이
전쟁이 신성감에서 오는 깊은 안전감을 기반으로 치러지면, 전쟁은 인격을 발달시키고 강화시킨다(Kalff, 2012). 내담자는 본능과 사회적 요구 간의 갈등, 의식과 무의식 간의 갈등을 이 런 전쟁으로 묘사하고 있는 것이다.

두 번째로 상담중기 II는 14회기 27회기(전쟁의 끝)이다. 14 회기에서는 '되게 좋다'며 젖은 모래를 많이 주무른다. 계속 물이 왼편 뒤 남성성의 영역에서 흐르는 강을 표현하는데 아 직 오른편 앞 여성성, 모성의 영역(Foks-Appelman, 2011)에 완 전히 닿은 느낌을 주지는 않는다. 열심히 운동을 한다. 학급 야 영을 엄청 재미있게 다녀온 후 15 회기에는 체에 모래를 올려 가슴을 생각나게 하는데 체질을 많이 하고, “높이 쌓고 싶다." 며 모래 위에 모래를 올리는 작업을 한다. 실생활에서 밤에 잠 을 자는 것이 많이 나아지고 체육대회 같은 학교활동에도 적 극적이다. 16 회기에는 바다가 있는 사막인데 여정이 힘드나 친한 친구랑 서로 돌보며 간다. 치료실 바닥에 집내부와 외부 의 소품으로 집의 안과 밖을 만들어 놓고 좋아한다. 집을 꾸민 것은 이제 안정감이 있다는 것, 안전기지가 생겨 편안해진 것 일 수 있고, 치료자와 내담자 간의 안정적인 관계의 표현일 수 도 있다(Esterhuyzen, 2014). 17회기의 '추락'은 연금술에서 응 고에 상응하는데 응고는 옛 형태가 분해된 후 일어나며 새로 운 무엇인가를 만들어 내는 것이다(Choi, Kim, Sim, \& Shim, 2009). 추락은 땅에 발을 디딘 것으로 정신적으로 올라갔다가 땅으로 내려온 것이고, 현실적이 되는 것이다. 내담자는 어른 스러우며 또한 유아적인데 친구들은 유치하니 같이 유치하게 엉켜 붙고 해야 하는 측면이 있다. 20 회기 모래상자처럼 내담 자는 이런 '난장판'이 필요하다. 이는 1 회기의 모래상자와 매 우 상반된 모습인데 적극적으로 부순다. 학교에서 축구를 하 는데 여자애들이 웃어도 괜찮아 하며 끝까지 뛴다. 모는 그렇 게 부끄러워하지 말라고 해도 안 되었는데 상담 받으며 되었 다며 좋아하신다.

21회기는 치료시간 내내 말없이 물과 모래로 철썩이는 작 업을 계속하는데 무의식과 깊이 관계하는 모습이다. 철썩이며 내면의 소리를 듣는 것 같고 자신의 본능, 감정과 접촉을 하며 내면이 회복되어 가는 것 같다. 22회기 역시 물을 철썩거려 모 래가 물에 씻겨 내리는 것을 찬찬히 본다. '절벽'을 만들었는데 노미노즘적이다. 절벽은 삶에서의 결정적인 순간, 즉 결정을 위한 시기로 정신의 남성적인 요소들과 여성적인 요소들에 관 한 것일 수 있고, 철저하게 새로운 것이 요구된다는 것을 의미 할 수 있다(Ackroyd, 1997). 이런 신비로운 경험은 모래놀이치 료의 언어이전의 특성(preverbal qualities)으로 가능한 것이다 (von Gontard, 2011). 23회기 역시 물과 모래를 철썩이는데 젖 
은 모래를 만지며 내담자 몸의 긴장이 완화되어 간다(Freedle, 2019). 우리는 물에서 태어났고 물은 치유 및 재생과 관련이 있다(Ackroyd, 1997; Chevalier \& Gheerbrant, 1996). 또한 연금 술에서 물은 용해(solution)와 동의어로 변형, 재구성을 위해 녹이는 것이다(Pattis, 2002).

24회기는 체질을 하고, 25회기는 전투, 투쟁장면이 이어진 다. 상담 전에는 집에서 옷을 지나치게 갖춰 입어 여름에도 단 추를 잠갔는데 지금은 팬티만 입고 돌아다닌다. 이는 내면에 자유로움이 생기며 실생활까지 이런 마음이 연결되어진 것이 다. 26회기에서는 추장 집으로 친구들이 왔는데 친구는 적과 대극으로 긍정적인 에너지가 온 것이다. 추장과 친구들이 원 형을 이루어 서로 대화를 하는데 원은 만다라로 조화롭다. 중 심에 불이 있어 따듯한 감정과 정감이 있다. 자연과 가깝고 원 시적인 모습으로 의식을 치루는 것 같다. 오아시스가 있고 식 물이 자라 내면이 성장하고 있음을 알 수 있다(Beavers, 2015). 27 회기는 전쟁이 끝난 후, 동물과 식물이 살기 시작했는데 이 는 본능과 감정이 올라온 것으로 이제 평온하고 자연스럽다.

마지막으로, 상담말기는 28회기 33회기(활기찬 일상으 로 돌아옴)이다. 28 회기의 눈 오는 마을은 차가운 마음과 정서 의 표현 같다. 눈길에 빠졌고 얼어 못 가나 도와주는 사람이 있 고 가로등과 소방서가 있어 어려움에 대처할 수 있겠다. 29회 기의 오토바이는 남성성과 관련이 있고(Ackroyd, 1997), 경주 는 진정한 자기나 어떤 중요한 인격발달을 의미한다(Ackroyd, 1997). 종착점에 있는 오벨리스크 몸체 사면에는 태양신에게 바치는 종교적 헌사나 왕의 생애를 기리는 내용이 담겨져 있 고, 꼭대기가 피라미드형으로 되어 있다. 이는 매우 남근적이 며 황금색으로 현자의 돌을 떠올리게 하는 금이다. 현자의 돌 을 얻는 것은 깨우침을 의미하는데 정신작업의 목표를 이루 어 변환이 완성되었음을 시사한다(Heathcote, 2009). 31회기 는 만든 상이 남근 모양으로 매우 강한 힘이 느껴진다. 최종회 기 33 회기의 마을중심에서 활동, 활기가 생겼다. 28 회기의 마 을은 중심이 비어 있는데 이제 활기를 많이 찾은 것을 알 수 있 다. 모래놀이치료에서 물과 모래를 가지고 놀며 감정과 본능 이 살아난 것이다. 놀이가 필요한 내담자에게 모래놀이치료 는 즐거운 놀이가 되었다. 23회기에서 내담자 스스로 '늘 심난 한데, 놀면 된다'며 놀이의 즐거움을 알게 되었고 여유로워진 모습이다. 오른편 앞에 다른 마을에서 오는 터널이 있는데 이 는 내부와 외부세계와의 연결, 소통이 이루어지고 있음을 표 현한 것이다. 1 회기의 만다라는 불안한 상태의 경직된 만다라 였으나, 최종회기의 만다라는 내면에 통합이 이루어진 것을 나타낸 것이다(Ammann, 2010; S. M. Kim, 1998). 청소년기 특
유의 정서적 문제나 심리적 특성은 자아정체감 형성과 관련 된 문제로 자기만의 독특한 자아개념이나 자아정체감을 가지 지 못하면 장기적인 목표, 직업 선택 등 여러 가지 문제에 대한 불확실감을 느끼게 되고 만성적인 공허감을 경험할 수 있는데 (Lee, 2015), 내담자는 이런 상태에서 원형적인 모에 회귀하고 전쟁을 치루며 강한 남성성을 회복하고 정서적인 어려움에서 자유로워져 활기찬 일상으로 돌아온 것이다. 모래놀이치료에 서 일상생활 장면이 나오면 이는 적응, 종료를 의미한다(Kalff, 2003; Turner, 2005).

내담자는 25 번의 촉감이 부드러운 델타샌드와 16 번의 주 로 모래를 만지는 작업을 하였는데 이는 손으로 태고의 정신 인 원형적인 모, 태고의 온전한 인간 능력의 잠재력를 가지고 발달되지 못한 자신의 귀중한 부분을 되찾는 작업을 행한 것 이다. $21,22,23,27$ 회기 치료시간 내내 아무 말 없이 물과 함 께 모래를 철썩거리는 부분은 손의 작업의 중요성을 재확인 시켜준다(Jang, 2017; Montecchi, 1999; Sim, 2014; Talamini, 2010). 이를 뒷받침하듯 내담자는 실물 같은 가슴 소품에 관 심을 보이고 모래로 모의 가슴과 몸을 만지는 것을 연상시키 는 작업을 많이 행한다. 손은 우리의 내면과 외면세계를 잇는 다리의 역할을 하고, 정신과 물질을 잇는 매개자이며, 손을 통 하여 존재하고 있던 에너지가 드러나게 된다(Ammann, 2009). 즉 깊은 무의식에서 작용하는 힘을 손으로 작업하여 보여주는 것이다.

요약하면, 본 연구의 내담자는 상담초기에 본능의 요구와 현실 간의 불균형으로 공허감을 드러내며 강한 남성성을 찾아 가는 여정을 시사하고 태고의 정신인 원형적인 모에게 회귀하 는 작업을 한다. 상담중기에는 투쟁으로 치열한 전쟁을 치르 며 전쟁을 마무리한다. 상담말기에는 강한 남성성을 회복하며 활기찬 일상으로 돌아오는 것으로 내면의 여정을 마친다.

본 연구는 남자 청소년이 원형적인 모에게 회귀하며 전쟁 으로 자신의 내면의 갈등을 표현하고 건강한 남성성을 회복하 는 모래놀이치료의 여정을 보여준다. 객관과 투사 심리검사에 서도 보여주듯이 모래놀이치료로 내담자의 주호소 문제가 완 화되어 모래놀이치료가 내담자에게 효과적이었음을 알 수 있 다. 모래놀이치료는 내담자의 무의식의 흐름을 따라 전개되는 것으로 무의식의 작업을 객관화하는 데는 한계가 있다. 그러 나 본 연구는 정서적인 어려움을 호소하는 남자 청소년이 퇴 행을 통해 원형적인 모, 온전한 인간 능력의 잠재력에 회귀하 고, 무의식의 여정에서 전쟁을 치열하게 치르는 등 원형적인 모와의 접촉, 전쟁, 대극의 역동적인 긴장 같은 원형적인 양식 (archetypal pattern), 초개인적인 심리과정을 통해 건강한 남성 
성을 회복하는 과정을 탐색하였다는데 의의가 있다. 또한 본 연구는 교육, 생활지도 및 상담장면에서 남자 청소년의 심리 를 이해하기 위한 기초자료로 활용될 수 있다.

\section{Acknowledgements}

This study was supported by the research year grant from Kunsan National University in 2019.

\section{Notes}

This article was presented at the 2019 Annual Fall Conference of the Korean Association of Child Studies.

\section{Conflict of Interest}

No potential conflict of interest relevant to this article was reported.

\section{References}

\section{In English}

American Psychiatric Association. (2013). Diagnostic and statistical manual of mental disorders (5th). Washington, DC: Author.

Ammann, R. (2010). The inner beauty of Hakoniwa: The inner beauty of sandplay therapy. Journal of Sandplay Therapy, 19(2), 7-19.

Anderson, M. (2009). Flooding and renewal: A girl's process of stabilization and renewal. Journal of Sandplay Therapy, 18(1), 83-105.

Anderson, M. (2019). Hands in the sand: Explorations, musings, reflections. Journal of Sandplay Therapy, 28(2), 73-87.

Beavers, K. (2015). Awakening the love within: A boy's sandplay process. Journal of Sandplay Therapy, 24(2), 45-65.

Bradway, K., Chambers, L., \& Chiaia, M. E. (2005). Sandplay in three voices. New York: Routledge.

Chevalier, J., \& Gheerbrant, A. (1996). Dictionary of symbols. London: Penguin books.

Cooper, J. C. (1978). An illustrated encyclopaedia of traditional symbols. London: Thames \& Hudson.
Esterhuyzen, A. (2014). The 'safe and sheltered space' of sandplay. Korean Journal of Sand Play Therapy, 10(1), 17-29.

Flahive, M. W. (2012). Shining stars in the dark night: Sandplay therapy with an adolescent male. Journal of Sandplay Therapy, 21(2), 85-102.

Foks-Appelman, T. (2011). Finding the path: The case of Anita. Journal of Sandplay Therapy, 20(1), 135-146.

Freedle, L. R. (2019). Making connections: Sandplay therapy and the neurosequential model of therapeutics. Journal of Sandplay Therapy, 28(1), 91-109.

Grubbs, G. (2007). The self and its evolving heaven and hell manifestations. Journal of Sandplay Therapy, 16(2), 75-86.

Heathcote, O. (2009). Infantile states in sandplay therapy a child's experience. Journal of Sandplay Therapy, 18(2), 89-109.

Henderson, J. L. (2005). Thresholds of initiation. Wilmette, IL: Chiron Publications.

Kalff, D. M. (2003). Sandplay: A psychotherapeutic approach to the psyche. Cloverdale, CA: Temenos press.

Manevsky, S. (2003). Fragile images of psyche. Journal of Sandplay Therapy, 12(1), 91-106.

Miles, R. (2012). The gateway: Boundary, entrance and threshold. Journal of Sandplay Therapy, 21(2), 21-38.

Montecchi, F. (1999). Hands that talk and analytic listening. Journal of Sandplay Therapy, 8(1), 25-67.

Napoliello, R. (2013, May). Neuroscience and symbolic process in sandplay. Paper presented at the annual meeting of the Korean Society of Sandplay Therapy \& Korea Association of Child Psychotherapy, Seoul, Korea.

Pattis, E. (2002). An angel weeps. Journal of Sandplay Therapy, 11(2), 9-15.

Porat, R., \& Meltzer, B. (1998). Images of war and images of peace. Journal of Sandplay Therapy, 7(2), 25-71.

Prins-Goodman, V. (2012). Initiation symbolism in adolescent sandplay therapy. Journal of Sandplay Therapy, 21(1), 99110.

Ronnberg, A. (2010). The book of symbols: Reflections on archetypal images. Köln, Land Nordrhein-Westfalen: Tasehen.

Schore, A. N. (2002). Dysregulation of the right brain: A fundamental mechanism of traumatic attachment and the psychopathogenesis of posttraumatic stress disorder. Australian and New Zealand Journal of Psychiatry, 36, 9-30.

Schwerdtfeger, A. (2016). The resurrection of Osiris burying trauma after 70 years. Journal of Sandplay Therapy, 25(1), $37-53$.

Talamini, M. (2010). The body unveils what the mind holds the case of Diana. Journal of Sandplay Therapy, 19(2), 41-59.

Turner, B. A. (2005). The handbook of sandplay therapy. Cloverdale, CA: Temenos press.

von Gontard, A. (2011). The numinous in sandplay therapy with children and adolescents. Journal of Sandplay Therapy, 
20(2), 103-124.

Winter, R. (1999). Sandplay and ego development. Journal of Sandplay Therapy, 8(1), 91-105.

\section{In Korean}

Ackroyd, E. (1997). A dictionary of dream symbols (B. J. Kim, Trans.). Seoul: Korean Psychotherapy Institute. (Original work published 1993)

Ammann, R. (2009). Der schopferische weg der personlichkeitsentwicklung (Y. -K. Lee, Trans.). Seoul: Analytical Psychology Center. (Original work published 2001)

Choi, Y. H., Kim, Y. H., Sim, H., Shim, M. K. (2009). Counseling for children. Seoul: Changkjisa.

Jang, M. (2017). Analytical psychological sandplay therapy. Seoul: Hakjisa.

Jeon, B. K. (2007). The study on how self-expression through sandplay therapy affects self-respect and personal relations of juveniles. Korean Journal of Sandplay Therapy, 3, 69-95.

Kalff, D. M. (2012). Sandspiel: Seine therapeutische wirkung auf die psyche (B. S. Lee, Trans.). Seoul: Hakjisa. (Original work published 2000)

Kim, H. J. (2011). The case study of sandplay therapy for a middle school boy with difficulties of adjustment to school. Korean Journal of Sandplay Therapy, 7(2), 29-57.

Kim, J. A. (2015). Effect of sandplay therapy in school counseling of emotional and behavioral problems in youth. Korean Journal of Sandplay Counseling, 11(2), 28-51.

Kim, J. S., Han, K. H., Im, J. Y., Min, B, B., Lee, J. H., \& Moon, K, J. (2005). Minnesota multiphasic personality inventoryadolescent (MMPI-A). Seoul: Maumsarang.

Kim, S.-M. (1998). Yungui simnihakgwa jonggyo [융의 심리학과 종교]. Paju, Gyeonggi: Dong Myeong.

Kim, Y. O., Park, S. M., Park, S. Y., Son, M., Shin, K. S., Lee, E. H.,... Hwang, H. S. (2009). Qualitative inquiry. Paju, Gyeonggi: Kyoyookkwahaksa.
Lee, J. K. (2006). Jiljeogyeongubangbeomnon [질적연구방법론]. Seoul: Kyoyookkwahaksa.

Lee, M. K. (2015). Analysis of the relation of youth depression and problem behaviors. The Hanyoung Academic Journal, 8, 157-178

Oh, K. J., Kim, Y. A., Ha, E. H., Lee, H. L., \& Hong, K. O. (2010a). Behavior checklist for child and adolescent-parents (CBCL 6-18). Seoul: Huno.

Oh, K. J., Kim, Y. A., Ha, E. H., Lee, H. L., \& Hong, K. O. (2010b). Youth self report (YSR). Seoul: Huno.

Rhi, B.-Y. (1987). Mother image and mother complex from the Jungian viewpoint. Shim-Song Yon-Gu, 2, 73-88.

Rhi, B.-Y. (2002). Self and self-actualization. Seoul: Hangilsa.

Sim, H. (2014). A case study of sandplay therapy for a middle school-aged boy having severe conflicts with his mother: Focused on initiation. Journal of Korean Home Management Association, 32(6), 1-18. doi:10.7466/JKHMA.2014.32.6.1

Song, H. (2017). Sturm und drang and mental health during adolescence. Korean Journal of Child Studies, 38(2), 1-3. doi: 10.5723/kjcs.2017.38.2.1

Yun, M. (2017). A case study on the sandplay therapy for the ego development and ego identity formation process of a schoolrefusing adolescent who exhibits complex trauma. Korean Journal of Sandplay Counseling, 13(1), 25-37.

\section{ORCID}

Hee-og Sim http://orcid.org/0000-0001-8790-6996

Received December 27, 2019

Revision received February 3, 2020

Accepted February 11, 2020 


\section{Appendix 1}

Projective pre-test \& post-test

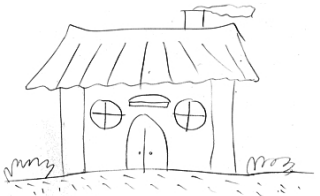

House(pre-test)

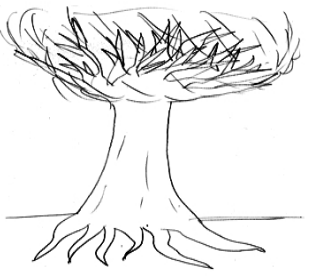

Tree(pre-test)

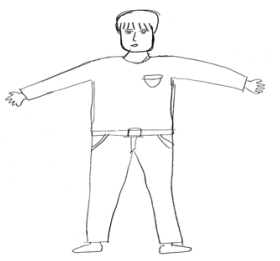

Person 1(pre-test)

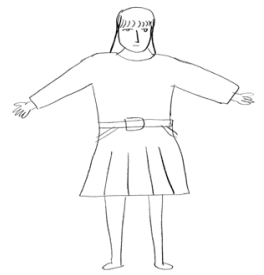

Person 2(pre-test)

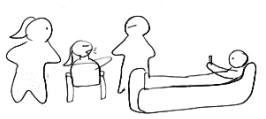

KFD(pre-test)

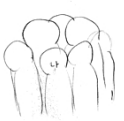

KSD(pre-test)

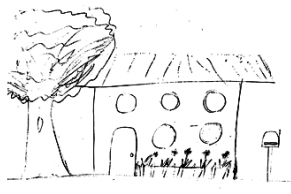

House(post-test)
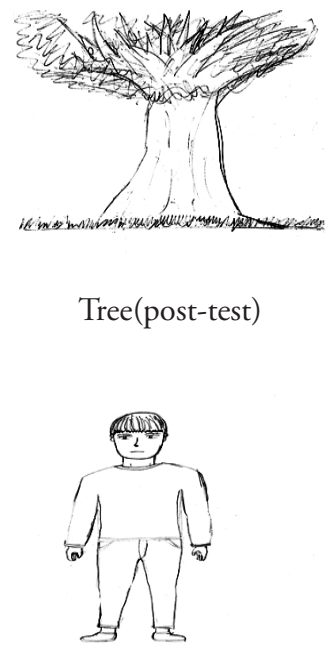

Person 1(post-test)

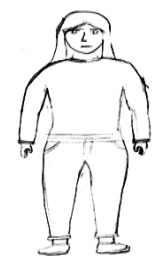

Person 2(post-test)

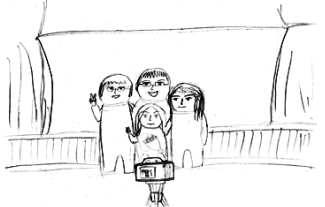

KFD(post-test)

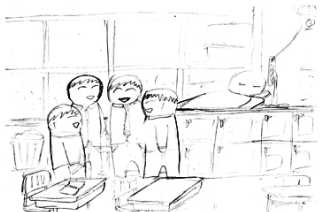

$\mathrm{KSD}$ (post-test)

Appendix 2

Sandplay therapy sessions

- The initial phase of therapy:

A sense of emptiness \& regression

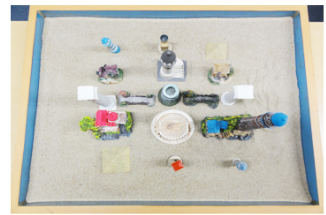

1-1 session(Untitled)

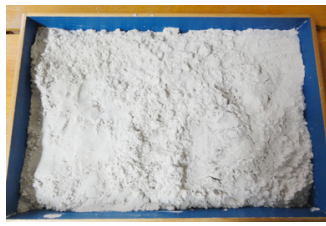

2-1 session(Untitled)

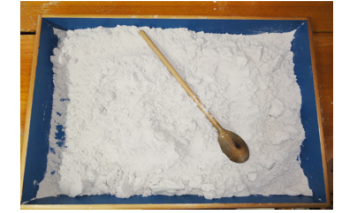

1-2 session(Volcano)

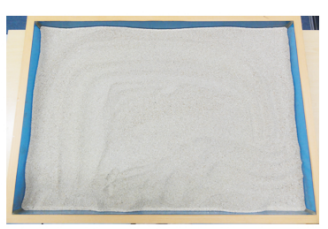

2-2 session(Wave)

- The intermediate phase: Struggle The intermediate phase I: Fierce wars

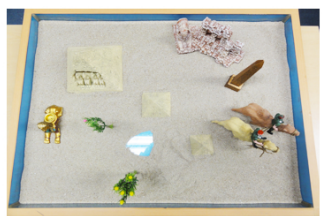

3-1 session

(Travel of desert)

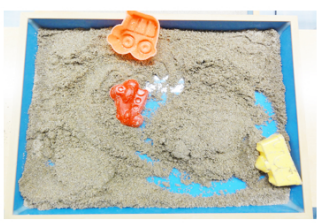

4-1 session(Untitled)

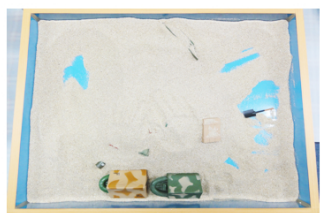

5-1 session(War)

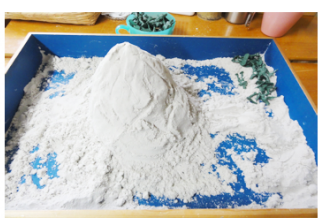

6 session

(Bamboo shoot)

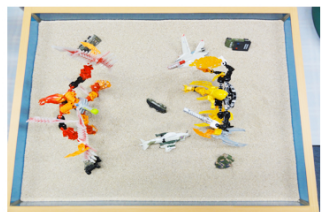

3-2 session

(Fights of villain)

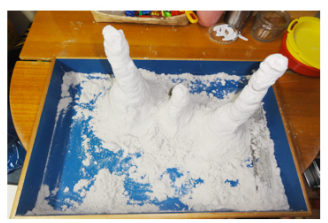

4-2 session

(Tower, intermediate phase)

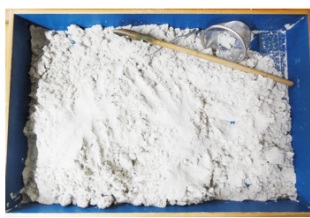

5-2 session(Untitled)

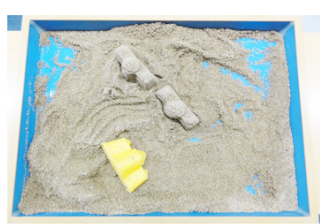

7-1 session(Untitled) 


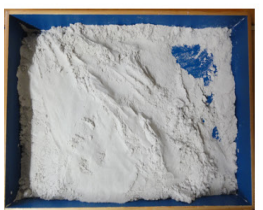

7-2 session

(Wave)

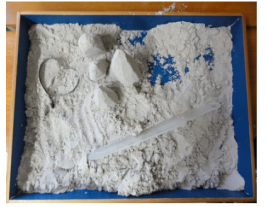

8-2 session

(Untitled)

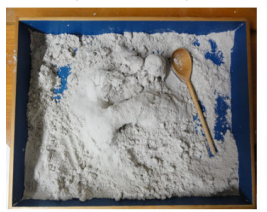

9-2 session

(Untitled)

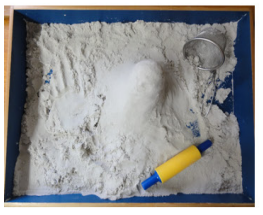

10-2 session

(Laugher)

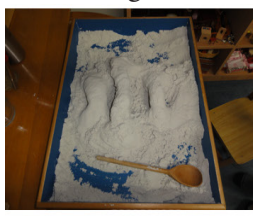

12 session

(Untitled, early phase)

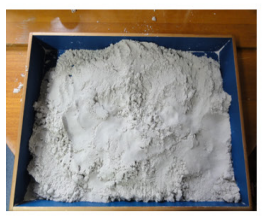

13 session

(Untitled)

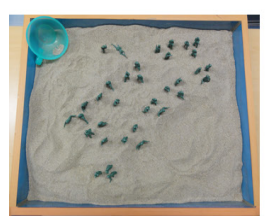

8-1 session

(Military)

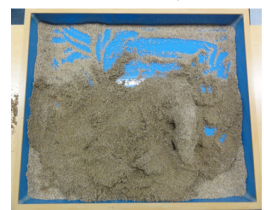

9-1 session

(Untitled)

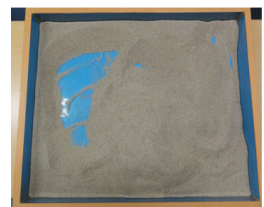

10-1 session

(Untitled)

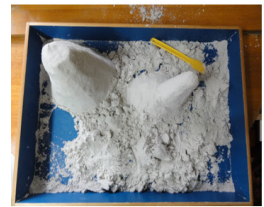

11 session

(Mountains)

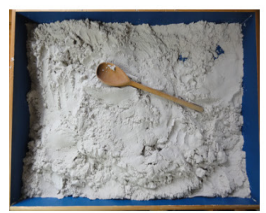

12 session

(Untitled)

- The intermediate phase II:

Ending of wars

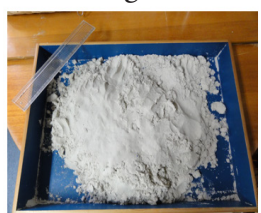

14-1 session

(Untitled)

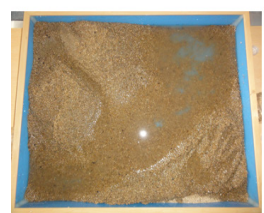

14-2 session (Lake)

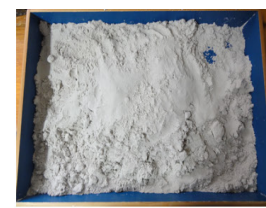

15 session

(Untitled)

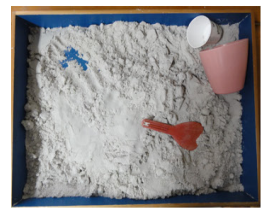

17-1 session

(Untitled)

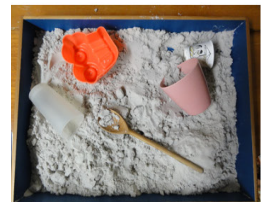

18 session

(Untitiled)

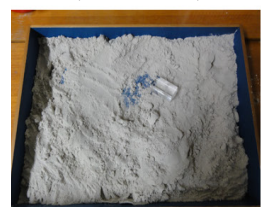

20 session

(Mess)

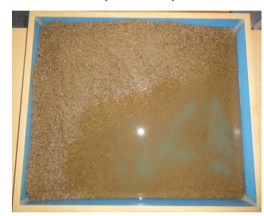

21-2 session

(Coast)

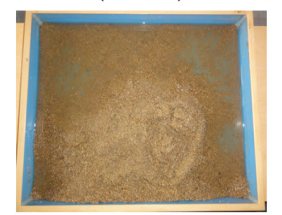

23-1 session

(untitled)

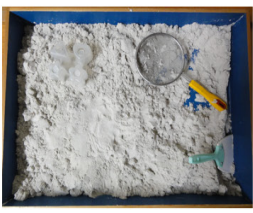

24 session

(Untitled)

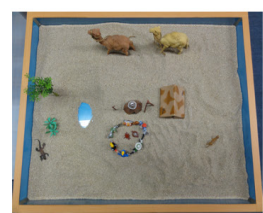

26-1 session

(Friends)

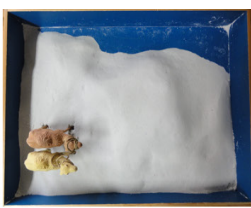

16 session

(Desert)

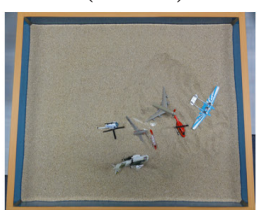

17-2 session

(Plunge)

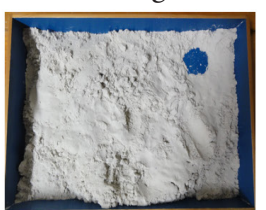

19 session

(Untitled)

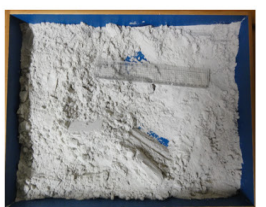

21-1 session

(Untitled)

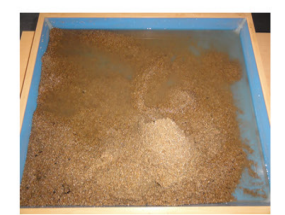

22 session

(Cliff)C

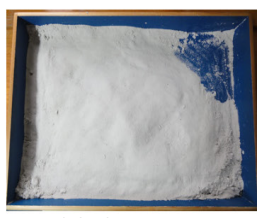

23-2 session

(Field)

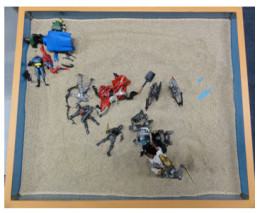

25 session

(Combat)

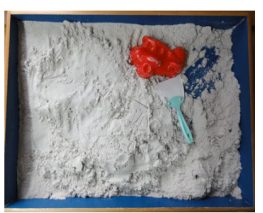

26-2 session

(Untitled)
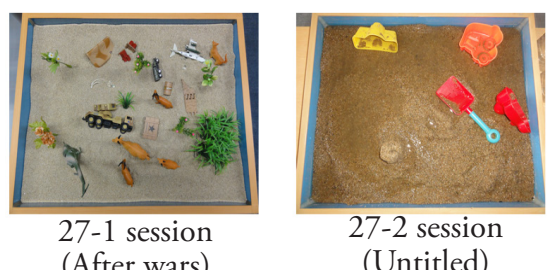

- The final phase: Active daily life

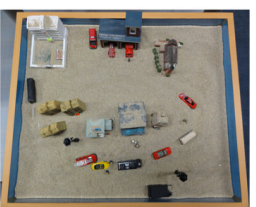

28 session (Village)

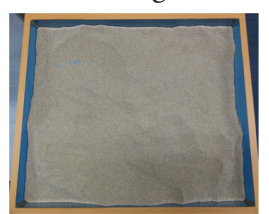

30 session

(Untitled)

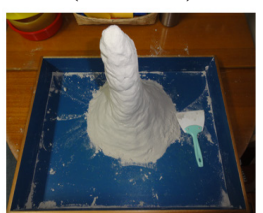

31-2 session

(Untitled)

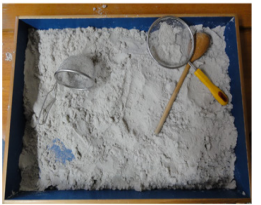

32-2 session

(Untitled)

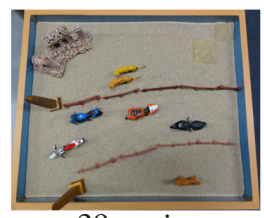

29 session

(Motorcycle race)

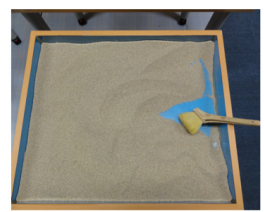

31-1 session

(Untitled)

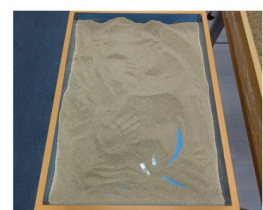

32-1 session

(Untitled)

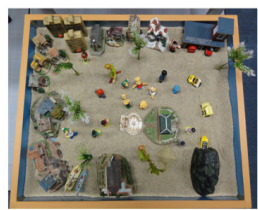

33 session

(Village) 